\title{
Regular online assessment, motivation and learning
}

\author{
Citation for published version (APA):
}

Rienties, B. C., \& Woltjer, G. B. (2004). Regular online assessment, motivation and learning. METEOR, Maastricht University School of Business and Economics. METEOR Research Memorandum No. 030 https://doi.org/10.26481/umamet.2004030

Document status and date:

Published: 01/01/2004

DOI:

10.26481/umamet.2004030

Document Version:

Publisher's PDF, also known as Version of record

\section{Please check the document version of this publication:}

- A submitted manuscript is the version of the article upon submission and before peer-review. There can be important differences between the submitted version and the official published version of record.

People interested in the research are advised to contact the author for the final version of the publication, or visit the DOI to the publisher's website.

- The final author version and the galley proof are versions of the publication after peer review.

- The final published version features the final layout of the paper including the volume, issue and page numbers.

Link to publication

\footnotetext{
General rights rights.

- You may freely distribute the URL identifying the publication in the public portal. please follow below link for the End User Agreement:

www.umlib.nl/taverne-license

Take down policy

If you believe that this document breaches copyright please contact us at:

repository@maastrichtuniversity.nl

providing details and we will investigate your claim.
}

Copyright and moral rights for the publications made accessible in the public portal are retained by the authors and/or other copyright owners and it is a condition of accessing publications that users recognise and abide by the legal requirements associated with these

- Users may download and print one copy of any publication from the public portal for the purpose of private study or research.

- You may not further distribute the material or use it for any profit-making activity or commercial gain

If the publication is distributed under the terms of Article $25 \mathrm{fa}$ of the Dutch Copyright Act, indicated by the "Taverne" license above, 


\title{
Regular Online Assessment, Motivation and Learning
}

$17^{\text {th }}$ of August 2004

Bart Rienties (Universiteit Maastricht), b.rienties@algec.unimaas.nl

Geert Woltjer (Universiteit Maastricht), g.woltjer@algec.unimaas.nl

\author{
Universiteit Maastricht \\ Department of Economics \\ P.O. Box 616 \\ 6200 MD Maastricht \\ The Netherlands
}




\title{
Regular Online Assessment, Motivation and Learning
}

\begin{abstract}
In 2002 regular online assessment was introduced as one of the pillars of an improved course in economics for business students. These online tests were introduced in the context of the problem-based teaching format used at Universiteit Maastricht, where students work in small groups guided by tasks. In this student-centred approach it is important that students come well-prepared to their group meetings. For students this is a type of Prisoner's Dilemma, because students can free-ride on the preparation of other students. It has also characteristics of an Assurance Game, because if a large part of the group is not well-prepared, the students that did prepare well will also get not much out of the group discussion and therefore will be less motivated to prepare for themselves, too. The risk that such an Assurance Game arises is higher when the majority of students is not intrinsically motivated at the start of the course. The interest in the subject matter of the course will certainly not increase when students do not study enough. Regular online assessment may help to solve these dilemmas by forcing students to prepare at least the textbook they have to read before the group meetings.

In this paper we discuss the role of online testing in the context of problem-based learning and show that after the introduction of online learning and other innovations students worked harder, had the feeling that they learned more and reported to be more interested in the subject-matter of the course (i.e. economics). It is obvious that the increase in work effort and motivation as the consequence of online testing is not limited to the context of a problem-based learning environment.
\end{abstract}

Key terms: online testing, economics teaching, educational innovation, ICT. JEL-codes: A2, A22 


\section{Introduction}

Universiteit Maastricht has used problem-based learning (PBL) as its main teaching format for over 25 years. In the problem-based learning system as implemented at Universiteit Maastricht, tasks direct the learning processes of students. During the first meeting, the so-called "pre-discussion", students discuss a task and formulate learning goals. Afterwards, students are expected to study and they discuss the task again in a second meeting, the so-called "post-discussion", where the students integrate the knowledge gathered during their study time. According to Gerritsen (1999: 128), the main advantage of using a problem-based learning system instead of traditional class teaching is that "knowledge is acquired in the meaningful context of a problem and that students have to work actively with this knowledge focusing on that problem".

The course Economics and Business is the only economics course within the first year International Business (IB) curriculum. The average IB-student is not very interested in abstract economic principles. Since these theories provide few links with the student's perception of his/her future career plans, students eventually become frustrated and unmotivated to study for economics courses. According to Donovan et al (2000, p.14), "students come to the classroom with preconceptions about how the world works. If their initial understandings are not engaged, they may fail to grasp the new concept and information that are taught, or they may learn them for purpose of a test but revert to their preconceptions outside the classroom." This was also the experience with the Economics course for International Business students. 
In order to improve the motivation and enthusiasm of the students and to increase the efficiency of the tutorial group meetings, a couple of educational innovations/experiments were introduced in 2002. A large case-study, intensive lectures focussing on linking real-world problems with economic theory, working in small subgroups, structured group post-discussion and frequent online testing were introduced. For a more elaborate description of these educational innovations, see Woltjer (2004b). In this paper we will focus on the use of regular online testing.

In this paper we will argue that regular online assessment may improve the problem-based learning system. First, a short introduction in the problembased educational system used at Universiteit Maastricht will be given and we will discuss a Prisoner's Dilemma that may arise in this teaching system; when students are not motivated for themselves, they may free-ride on work of others, and both their motivation and the motivation of the others will decrease. Then we will dig deeper into the use of online testing to solve this dilemma. Finally, we will discuss the tutor and student evaluations of the course. We will conclude that the first results of the course indicate that the online tests are effective in motivating students to work and therefore solving the Prisoner's Dilemma that may arise during tutorial groups. 


\section{Educational philosophy at Universiteit Maastricht}

Universiteit Maastricht is known in the Netherlands for its problem-based learning philosophy (PBL). "Problem-based learning was first introduced in 1969 in the Medical Faculty of the McMaster University in Hamilton, Canada" (Moust et al., 2001, p. 11). At Universiteit Maastricht, problem-based learning was introduced in 1974 at the Faculty of Medicine. According to Barrows (1984), the main advantages of PBL are first, the acquisition of applicable knowledge, second, learning-to-learn (self-directed learning) and finally the ability to analyse and solve problems. Moust et al. (2001) suggests that these advantages will not become apparent without students having an active learning attitude.

The general structure of a typical PBL-session looks as follows: Students pre-discuss one or two tasks in a group of about 12 students under supervision of a junior teacher, a tutor, without preparation in advance. The group formulates problem-statements from the task and brainstorm about possible answers or solutions. During this pre-discussion students will become aware of the knowledge they already possess, and students may help each other by sharing knowledge and ideas. During the group discussion about the task students will become aware of the knowledge and insights they are missing. This is an incentive to study for the students. Therefore, at the end of the group discussion so-called "learning goals" are being formulated.

After some days, the group meets again for the post-discussion of the tasks, where the students report what they found during their study at home. The purpose of the post-discussion is to report and integrate the information gathered during the study period between the two group sessions. 
During the tutorial group sessions, the tutor has an inactive role and he/she only has to facilitate the process of the group and provide feedback on the quality of the arguments raised in the group as well as on the formulated learning goals. By asking questions the tutor may help students to raise the level of the discussion to a higher level.

According to Moust et al. (2001, p. 16), working in small groups has four main advantages in comparison to traditional classroom teaching. First, students motivate each other to study when discussing and listening to each other. Second, the group provides a reference for the student to what extent his/her learning process is comparable with his/her fellow-students. Third, during the tutorial group meetings students acquire communicative skills which are necessary in their future career. Finally, students learn to work together and to collaborate.

The quality of the discussions and the extent of learning are heavily dependent on the quality of the course, the chosen literature and the motivation of individual students to contribute to the group discussions (moral incentives). Due to the large number of students, large searching costs and limited library facilities, most courses of the Faculty of Economics and Business Administration have textbooks instead of (a list of) articles where students have to choose which article is relevant. A risk of using a textbook in undergraduate courses is that the post-discussions will become "summary-sessions" of the textbook, rather than a discussion about the learning goals and integrating additional insights/articles into the discussion. The motivation of the student is of crucial importance whether the group discussions provides added value, and 
motivation seems to be dependent on the moral incentives of the respective student and on the group as a whole. In general, moral incentives are difficult to manage and control. If too many students free-ride on the group discussions, a Prisoner's Dilemma might develop where the other group members will become frustrated and eventually stop participating as well.

Assuming that students who prepare for the post-discussion will participate in class as well, the decision to prepare for class depends on intrinsic motivational factors and on the decisions made by the other students. If we simplify the problem to a two-person Prisoner's Dilemma, the problem may look as in table 1 . The overall utility of the group is highest when both students prepare and participate. However, if Student I prepares and participates in class, Student II can benefit from Student I's knowledge without having to read the literature. Student II can spend more time doing other things than studying, increasing his overall utility (11). Since Student I will not receive any additional insights from Student II, and Student I has to make all effort in answering the learning objectives, Student l's utility will be lower (5). In this example, the dominant strategy of the two students (Nash equilibrium) will be not to prepare for the post-discussion. The group process of learning together will stagnate or fall apart.

Table 1 Prisoner's Dilemma of Preparing for post-discussion

\begin{tabular}{|l|l|c|c|}
\hline \multicolumn{2}{|c|}{ Student II } \\
\hline \multirow{2}{*}{} & & Prepare & Do not Prepare \\
\cline { 2 - 4 } & Prepare & $(10,10)$ & $(5,11)$ \\
\cline { 2 - 4 } & Do not Prepare & $(11,5)$ & $(7,7)$ \\
\hline
\end{tabular}


The group performance problem can also have the characteristics of an Assurance Game (see Poundstone 1993 for a description of this game). If all students are well-prepared, all students can get much out of the postdiscussion. But if the majority did not prepare well, the discussion can not go much further than discussing what everyone should know if they would have read the textbook. So, for the students that did not prepare, the group meeting is a sort of substitute of reading the textbook, and for the well-prepared students, it is a waste of time, although it can always be useful to formulate for yourself what you did read in the textbook (see table 2, for a numerical example with two people). So, in this case there is not only free riding, but the problem that no one gets much out of the group.

Table 2 Assurance Game of Preparing for post-discussion

\begin{tabular}{|l|l|c|c|}
\hline \multicolumn{3}{|c|}{ Student II } \\
\hline \multirow{3}{*}{ Student I } & Prepare & Do not Prepare \\
\cline { 2 - 4 } & Prepare & $(10,10)$ & $(4,6)$ \\
\cline { 2 - 4 } & Do not Prepare & $(6,4)$ & $(5,5)$ \\
\hline
\end{tabular}

It is obvious that the risk that students do not prepare depends on the motivation for the subject matter of the course, and can also be influenced by the behaviour of the tutor. Business students tend not to be too motivated for Economics courses. In such a situation it is very difficult for the tutor to motivate a group of unmotivated students. When students do not prepare, they will not get an opportunity to become motivated for the course. Therefore, the dilemma will become worse and worse (again, an Assurance Game). 
We have chosen for a partial solution of this problem by forcing students to do online tests before the meetings. Although students may not like the obligation in first instance, they may find out that it makes the groups more fruitful. And when forced to study they may even become more interested in the subject matter.

\section{Set-up of the online tests}

Assessments can be distinguished in two major forms: formative assessments and summative assessments (Donavon et al., 2000; and Rovai, 2000). Formative assessments are used as a source of feedback to improve the teaching and learning during a course, like teacher's comments on a draft of a paper, a presentation or assignment. Summative assessments are tests that assess whether students have learned enough and are able to apply their knowledge to particular problems. In general, summative tests can be regarded as high-stake exams. According to Donovan et al (2000, p. 141), "feedback is most valuable when students have the opportunity to use it to revise their thinking as they are working on a unit or project."

In the course Economics and Business, the purpose of the online tests is formative. We want students to stimulate to read at least the textbook, and we want them to give feedback to what extend they were succesful in this. However, in order to prevent that students are not doing the tests, or don't work hard on it, we require students to pass those tests, introducing a summative element in the tests. The basic idea is that students that did prepare sufficiently and are able to finish the course, will have no problems in passing the online tests. The grades on the online tests are not part of the final grade for the 
course. The real summative moment is at the end of the course, when students have to do the written exam.

Before each post-discussion, all four hundred students had to make a unique individual online test. A typical online test consists of 20 questions, which are randomly drawn from a database in our Virtual Learning Environment (Blackboard). The questions come from a course cartridge of the textbook we use (Frank and Bernanke, 2003). The course cartridge has a database of about 200 multiple-choice questions per chapter. A relatively large part of those questions are applied. Therefore, students learn to apply the theory and gain additional insights by playing around with graphs, tables and simple mathematics. However, the basic idea is that the students will be forced to read the textbook carefully and that in this way the quality of the post-discussion in the tutorial groups is improved.

The online testing system has been used twice thus far. During the academic year 2002-2003 the set-up was experimental. Students could make their online tests as many times as they wanted to until they received a 7.0 or higher. As a consequence there was a danger that some students would repeat the exams a lot of times instead of reading the textbook. Since questions are always a little bit selective, for example focusing on problems that can be calculated easily, this is not optimal. Therefore, we decided not to give feedback in order to prevent that students could study with the tests instead of reading the textbook.

A different set-up was chosen in the academic year 2003-2004. The basic idea was that we could increase the amount of feedback if students were 
restricted in the number of tests they could do. We gave students two opportunities to do the test, the so-called "practice Eleum test" and "official Eleum test" (see figure 1; Eleum stands for Electronic Learning Environment Universiteit Maastricht). As the word implies, the practice test was meant for students to test whether one has already studied sufficiently to make the official test. The official test was the test that they had to pass before the postdiscussion in the tutorial group. If a student passed less than five of the six tests, he/she had an opportunity to retake the missed tests during the week before the exam. All students could use those tests in the exam week as practice for the final written exam. If after this second opportunity the student passed less than five tests with a six or higher, the student had to do an assignment, which boiled down to writing a paper with a workload of approximately 40 hours.

Figure 1 Structure of online testing in Economics and Business 2003-2004

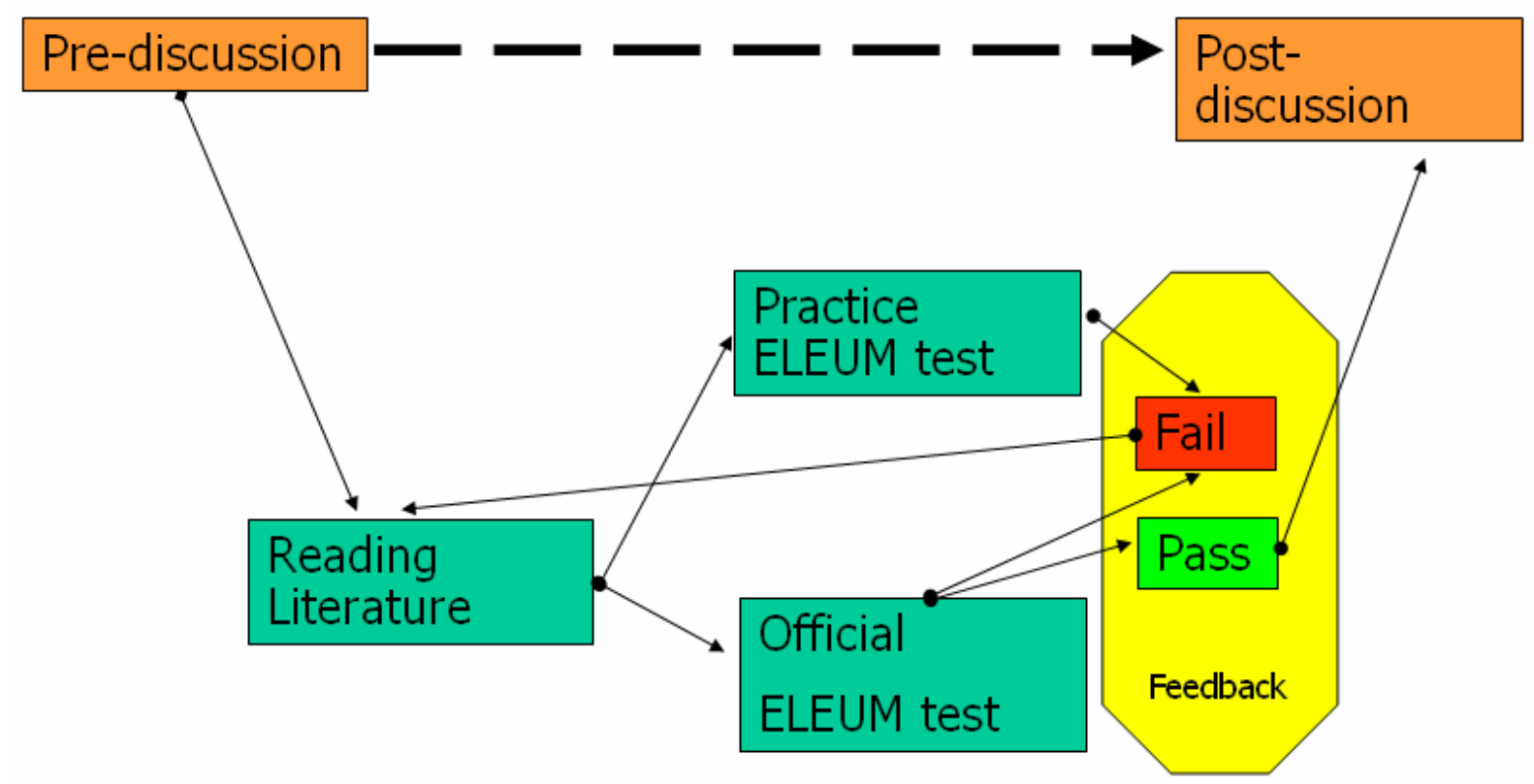


The online tests have benefits both for the students and the tutors. The main benefits for students is that they receive immediate feedback and that students are better prepared for the post-discussion, thereby (partly) solving the Prisoner's Dilemma and Assurance Game discussed before. By making the online tests, students receive feedback about which parts of the chapter(s) are well understood and which parts need more attention. The student also receives feedback where in the textbook one can learn more about a particular problem (formative assessment). In order to give also advantages to the students in their exam, we decided to draw $40 \%$ of the questions in the final exam from the same database as the six online tests. By frequently using the online testing tools, the learning process is better structured; students learn to make multiple choice tests and to apply the theory with the help of graphs and mathematics to more complicated issues. For the tutor, the advantages of regular online assessment should be apparent, since more/all students are prepared for the post-discussion. Therefore, the tutor will have to intervene less in the group and the discussions reach a higher level of quality.

If you force students to do an online test before a specific date, it is important that the technology is reliable, and the database of questions is of a high quality. During our runs we had problems with both. For example, a bad timing of maintenance of the Blackboard servers just before the deadline of one of the online tests and some crashes of the servers made students feel uncomfortable about the tests. It required us to extend the period that students could do the tests, and this was only possible by creating additional tests. Sometimes the connection with the computer of a student was lost when a 
student was making a test, and an assistant had to reset the test for such a student. It is important that this type of problem doesn't happen too often. Sometimes we heard complaints about questions that we not complete or with incorrect feedback. It is obvious that too many of this type of problems can be disastrous for the motivation of the students.

In order to remove (part of) the feeling of an "unreliable" testing-system, we published after each test a graph showing how many people passed (on average 80 per cent), with which grade (average of 7.4 with a standard deviation of 0.92 ; so, far above the required level of 6.0 ), and how many real technical failures there were (on average two per test). We also explained to the students that we expect them to be able to pass the tests with at least a 7 , but that because of the existence of incorrect questions we lowered the norm to a 6 . In summary, the set-up of the online tests is very important. A reliable server for the online learning environment, reliable computer connections and a high quality database of questions is very important.

\section{Student evaluation of the online tests}

At the end of the course we asked the tutors of the 30 tutorial groups about their experience with the online tests, and all students that were at the last tutorial group meeting filled in a questionnaire about the course. In this section we will report the main results, and compare those with past evaluations of the course.

Although there clearly were some technical problems, a short evaluation by the tutors seems to indicate that the general effects were positive. The tutors had the feeling that, in contrast to other undergraduate courses, all students 
had read the literature before they came to the post-discussion. The discussions seemed to be less focussed on explaining basic issues from the textbook and the discussions went to a deeper level. Except for one group with serious concerns about the appropriateness of online testing, all other groups indicated that online testing was useful despite the technical problems and additional workload. From most tutors we heard criticism about the number of questions in the database that were not correct (about 5\%).

The students were relatively positive about the online tests. The question "I think that the set-up and use of ELEUM-tests in this course is valuable" was evaluated with 3.4 on a scale of $1-5$, where 1 indicates totally disagree and 5 indicates totally agree. Better students, measured as students with a grade of 7 or higher in the mathematics and statistics course (30\% of the students) evaluated the question even with a 3.6 , with about $60 \%$ of those students explicitly positive about the use of the online tests. These figures are remarkably high given the amount of (technical) problems with the reliability and availability of the online tests and the increased working pressure on students.

Below we will put the other results of the questionnaire in the perspective of the last five years. Online testing is only part of the improvements of the course Economics and Business and therefore is not the only explanation behind the results. The causalities of the different relationships seem to be very complex and have to be investigated further. Furthermore, the group of students changes every year. In addition, the organization of the course Economics and Business has changed quite dramatically over the last five years, therefore making a direct comparison between the courses over time more difficult. 


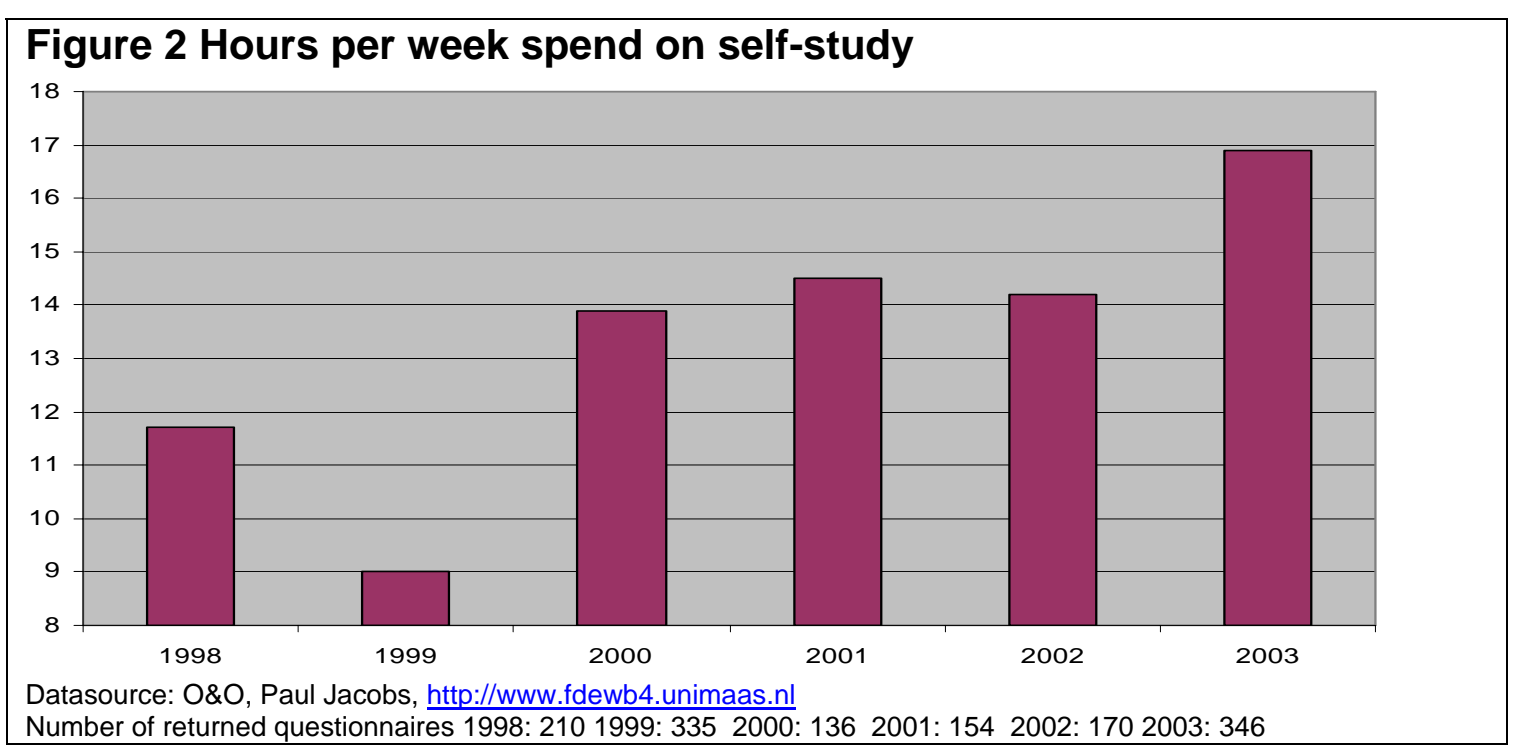

The first idea behind the introduction of online assessment in the course was that regular online assessment improves the work effort of the students. A standard measure used to analyse work effort at the Faculty of Economics and Business Administration is the question "How many hours per week (on the average) did you spend on self-study (presentations, cases, assignments, studying literature, etc)?" Given that students are expected to study in total including lectures and group meetings for 40 hours per week and that a block period has two parallel courses, each student should self-study for approximately 14 hours per week per course. In practice, this figure is hardly found and a 10-12 hour workweek per course is a more realistic estimation. As one can see in figure 2, the hours of self-study were lowest in 1999 and have since then gradually improved. Although the hours worked in 2002, when the new course set-up was introduced, are lower than the two years before, one should note that the formal work-load of the course has decreased from 6.5 to 4.5 credits and the number of tutorial group meetings decreased from 14 till 9. Therefore, the number of hours worked per credit has actually increased. In 
2003, the hours worked was the highest in six years, which indicates that workeffort is (partly) stimulated by online testing. The number of hours worked is also high compared with the parallel courses accounting (both for Economics and International Business students) and micro-economics (only for Economics students): respectively 12.5 and 12.9 hours compared with 16.9 in the Economics and Business course. So, students certainly worked more than in the past and compared with the parallel courses.

The second purpose of the online assessment was to improve the motivation of the students. Although motivation is difficult to measure, the questions "In general, I've worked enthusiastically during this course" and "I found the subject-matter in this course interesting" in combination with the time spend on a course (see figure 2) and the overall course grade seem to be a good approximation. As is illustrated in figure 3 , enthusiasm tumbled from 3.5 in 1998 to 3.2 in 2001 . Since the introduction of online testing and several other innovations, enthusiasm has increased to 3.8 in 2003. Also the interest in the subject-matter of the course (i.e. Economics) rose from 3.5 or lower to 3.9. 


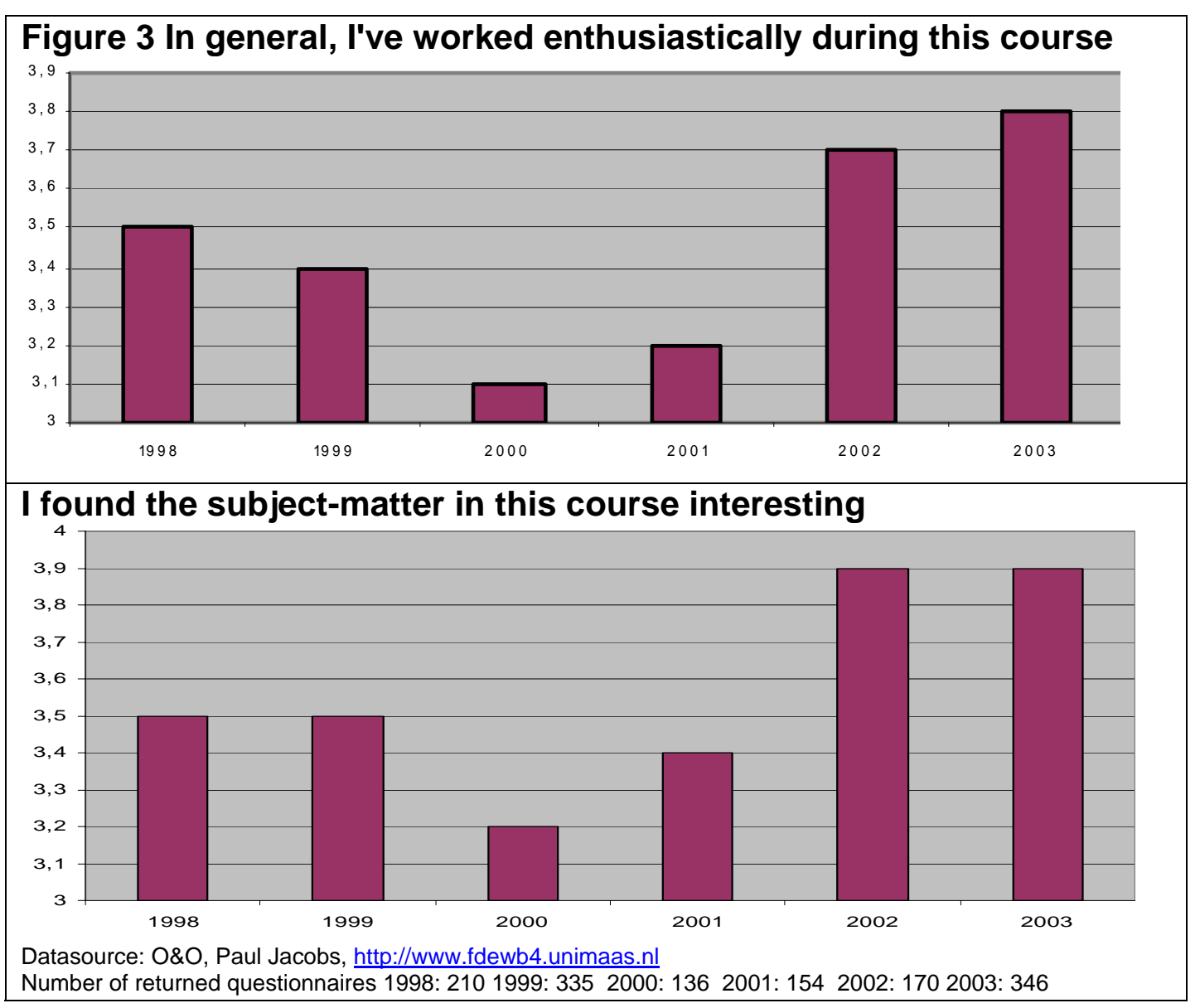

In addition, students had to give an overall grade for the course, which is a rough approximation of the overall satisfaction of the student on the course. This course grade has increased since the new course structure has been introduced (see figure 4). These figures are on a scale of $0-10$, where 0 is really bad, 5.5 is sufficient and 10 excellent. Most likely, due to some start-up problems (e.g. no feed-back on online assessment, limited knowledge of assessments) with the new innovative course structure in 2002, the evaluation was not as high as originally expected. With the experiences gathered in 2002, the improvement in online testing and other aspects of the course resulted in a rise of the overall course grade to 7.1 in 2003. 


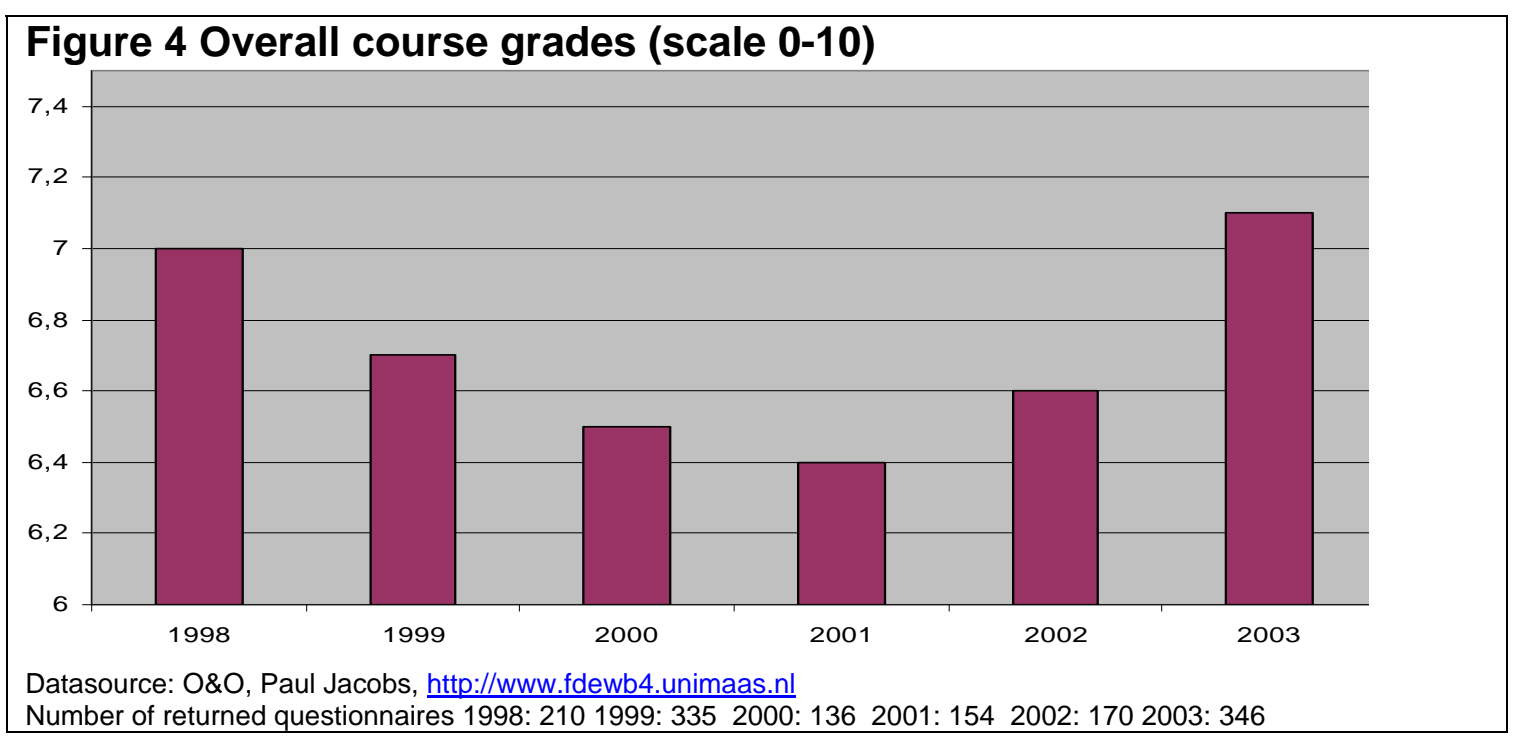

Finally, the online tests should improve the learning process. The statements "I learned a lot during this course" is an indication of the amount they learned in combination with the evaluations of the tutors and our feeling that we had a more difficult final exam without worse results.

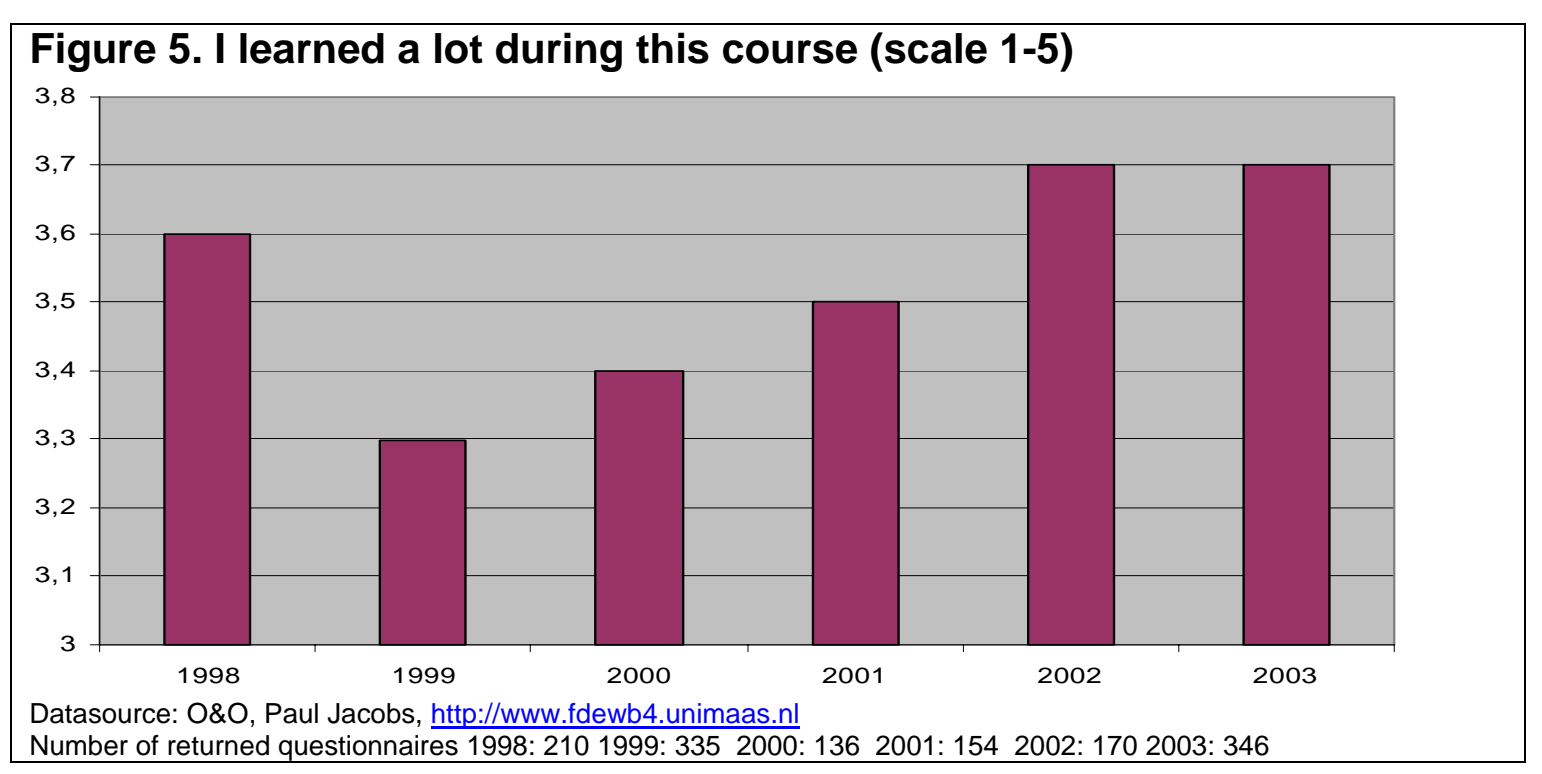

To sum up, students are more positive about the course in comparison to the last couple of years. Despite fewer group meetings (9 instead of 14) but with more E-learning and other educational innovations, the structure of the course 
had led to a higher motivation, more learning, higher work effort and higher overall evaluation of the course.

\section{Conclusion}

The introduction of regular online testing in the problem based teaching format for the Economics course for Business students was motivated by the lack of motivation and working effort by the students during the old course setup. Although regular online testing seems not to be consistent with the idea behind problem-based learning, it can solve an important Prisoner's Dilemma or Assurance Game in situations where students are not directly motivated for the course and tend not to prepare enough for the post-discussion to be really fruitful. Online testing seems to be a solution for this problem. Although not all technical problems had been solved, the course evaluation suggests large improvements in work effort, motivation and experienced learning by the students. Compared with other courses the work effort was remarkably high during this course. Because the new course set-up had more innovations than the online tests alone, the results have to be interpreted with care. Nevertheless, the general impression is that the online tests were successful in forcing the students to work more regular during the course and increasing their enthusiasm for this course they were not interested in a priori. It is obvious that the increase in work effort and motivation of online testing is not limited to the context of problem-based learning. 


\section{References}

Donovan, M.S., Bransford, J.D., \& J.W. Pellegrino, eds., (2000). How People

Learn: Brain, Mind, Experience, and School. National Academy Press, Washington, DC.

Frank, R.H. \& Bernanke, B. (2003). Principles of Economics, International Edition. McGrawHill/Irwin, Second edition.

Gerritsen, R.J. (1999). Do students study more thoroughly within a problembased learning course'. In: Hommes, J. et al. (ed.), Learning in a changing environment. Educational innovation in Economics and Business IV, Kluwer, pp 127-142.

McDowell, L. (2004). Formative assessment using testing facilities in Blackboard: principles and strategies. Recap Series. University of Northumbria.

Moust, J.H.C., Bouhuijs, P.A.J, \& Schmidt, H.G. (2002). Problem-based learning: a student guide. Groningen : Wolters-Noordhoff.

Navarro, P. (2000). Economics in the Cyberclassroom. Journal of Economic Perspectives. 14 (2), 119-132.

Poundstone, W. (1993). Prisoner's Dilemma: John Von Neumann, Game Theory and the Puzzle of the Bomb. Oxford University Press.

Rovai, A.P. (2000), Online and traditional assessments: what is the difference? Internet and Higher Education, 3, 141-151.

Sclater, N.; \& Howie, K. (2003). User requirements of the "ultimate" online assessment engine, Computers \& Education, 40, 285-306. 
Woltjer, G. (2004a). Crude oil: using a large case to teach introductory economics. Meteor Research Memorandum, RM/04/014.

Woltjer, G. (2004b). An efficient format for a problem based introductory economics course. Meteor Research Memorandum. RM/04/015. 